Original Research Paper

\title{
Pembuatan Abon dari Ikan Tuna Sebagai Salah Satu Alternatif Wirausaha Baru di Desa Batu Nampar Selatan
}

\author{
Mahrus $^{1}$, Abdurrazif $^{2 *}$, Dedi Zulkarnaen ${ }^{2}$, Wiwik Febrianti ${ }^{2}$, Ahmad Nur Alfin Rizki $^{3}$, Andrey Darusman ${ }^{3}$ \\ ${ }^{I}$ Fakultas Keguruan dan Ilmu Pendidikan, Universitas Mataram, Mataram, Indonesia \\ ${ }^{2}$ Fakultas Hukum, Universitas Mataram, Mataram, Indonesia \\ ${ }^{3}$ Fakultas Peternakan, Universitas Mataram, Mataram, Indonesia
}

DOI: https://doi.org/10.29303/jpmpi.v4i2.824

Sitasi: Mahrus., Abdurrazif., Zulkarnaen, D., Febrianti, W., Rizki, A. N. A., \& Darusman, A. (2021). Pembuatan Abon dari Ikan Tuna Sebagai Salah Satu Alternatif Wirausaha Baru di Desa Batu Nampar Selatan. Jurnal Pengabdian Magister Pendidikan IPA, 4(2)

\author{
Article history \\ Received: 30 April 2021 \\ Revised: 23 Mei 2021 \\ Accepted: 30 Juni 2021 \\ *Corresponding Author: \\ Abdurrazif, Fakultas Hukum, \\ Universitas Mataram, Mataram, \\ Indonesia; \\ Email: elzarjura@gmail.com
}

\begin{abstract}
Batu Nampar Selatan merupakan salah satu desa yang berada di Kecamatan Jerowaru, Kabupaten Lombok Timur, Provinsi Nusa Tenggara Barat. Desa ini memiliki penduduk sebanyak 1.356 jiwa terdiri dari 677 laki-laki dan 679 perempuan, dan 336 kepala keluarga. Luas wilayahnya $2,99 \mathrm{~km}^{2}$ dengan tingkat kepadatan penduduk $454 \mathrm{jiwa} / \mathrm{km}^{2}$. Mata pencaharian penduduk sebagian besar sebagai nelayan di antaranya sebagai nelayan tangkap, nelayan budidaya, dan sebagian kecil sebagai petani. Salah satu upaya untuk meningkatkan taraf kehidupan ekonomi masyarakat adalah pembentukan kelompok wirausaha yang memproduksi suatu produk dengan memanfaatkan hasil tangkapan nelayan. Untuk mengefektifkan kegiatan wirausaha ini dilakukan sosialisasi dan pelatihan kepada masyarakat dengan melibatkan pihak Dinas Sosial Pemerintah Kabupaten Lombok Timur. Implementasi program penciptaan wirausaha baru "Pembuatan Abon dari Ikan Tuna di desa Batu Nampar Selatan Kecamatan Jerowaru kabupaten Lombok Timur" ini diharapkan mampu meningkatkan kesejahteraan masyarakat. Selanjutnya dengan peningkatan kesejahteraan masyarakat, maka dengan sendirinya mereka dapat berpartisipasi aktif dalam pembangunan desa.
\end{abstract}

Keywords: Wirausaha; Perikanan; Nelayan Tangkap; Nelayan Budidaya; Kesejahteraan.

Mata pencaharian penduduk Desa Batu Nampar Selatan sebagian besar di bidang perikanan terutama sebagai nelayan bidang budidaya, dan nelayan tangkap, serta sisanya di bidang pertanian sebagai buruh tani, dan peternakan. Ketersediaan lapangan kerja sangat minim dikarenakan tingkat pendidikan masih rendah yang berdampak pada permasalahan jumlah masyarakat miskin cukup tinggi yaitu sekitar 62\% (Abdurrazi dkk., 2021).

Berdasarkan permasalahan di atas, maka diperlukan suatu terobosan program seperti pemberdayaan masyarakat miskin seperti pembentukan wirausaha baru melalui pembuatan abon ikan tuna. Kehadiran program pemberdayaan masyarakat miskin melalui penciptaan wirausaha 
baru ini didasarkan pada nilai tambah yang diciptakan berupa nilai ekonomi tinggi. Nilai tambah yang tercipta dari kegiatan pembuatan abon ikan sebesar Rp 194.434/kg dengan keuntungan Rp 173.302/kg (Dzulmawan dkk., 2019). Seseorang atau sekelompok orang pada umumnya kurang menyadari potensi yang dimiliki yang bila dikembangkan dapat melebihi kemampuan dari orang biasa (Prihadi, 2004).

Untuk mewujudkan program wirausaha baru tersebut diperlukan kerjasama antara LPPM Universitas Mataram dengan Dinas Sosial Pemerintah Kabupaten Lombok Timur. Melalui kegiatan KKN Mahasiswa Universitas Mataram harus berperan aktif dalam penciptaan wirausaha baru di Desa Batu Nampar Selatan. Beberapa peran yang dijalankan adalah melakukan identifikasi potensi usaha di setiap dusun, melakukan percobaan pembuatan produk yang mempunyai nilai jual tinggi berbahan baku hasil tangkapan ikan, sosialisasi dengan mengundang masyarakat desa, pelatihan wirausaha, pembentukan kelompok kewirausahaan. Dari sejumlah program yang dilaksanakan diharapkan dapat meningkatkan kesejahteraan masyarakat.

Secara umum tujuan dari program penciptaan wirausaha baru ini adalah mengentaskan kemiskinan dan mewujudkan kemandirian masyarakat baik secara ekonomi maupun sosial. Sasaran dari program penciptaan wirausaha baru ini adalah masyarakat yang memiliki berbagai keterbatasan penghasilan, pendidikan, perumahan, keterampilan, hubungan sosial, serta mempunyai keinginan untuk berkembang dan mandiri (Ali dan Asrori, 2014; Achmad, 2015).

Selain itu, diharapkan juga upaya ini dapat berkelanjutan untuk meningkatkan pengetahuan masyarakat yang akan mendorong mereka untuk berpartisipasi akan pentingnya berwirausaha, oleh karena itu program wirausaha baru pembuatan abon ikan tuna di Desa Batu Nampar Selatan penting dilakukan.

\section{Metode}

\section{Waktu dan Tempat}

Kegiatan wirausaha ini dilakukan selama 45 hari periode KKN terhitung mulai dari tanggal 11 Januari - 25 Februari 2021 di Desa Batu Nampar Selatan.

\section{Bahan}

Bahan yang dibutuhkan di dalam pembuatan abon ikan adalah ikan tuna sirip kuning, jeruk nipis, bumbu seperti gula, bawang putih, lengkuas, cabe merah besar, bawang merah, bawang putih, gula pasir, garam dapur dan lainnya.

\section{Metode}

Kegiatan wirausaha ini berupa pembuatan abon dari ikan tuna sirip kuning dilakukan dengan menggunakan metode pelatihan. Metode pembuatan abon menggunakan modifikasi dari beberapa metode (Kusumayanti dkk., 2011; Setiawati dan Sri (2018). Beberapa tahapan kegiatan yang dilakukan yaitu sebelumnya diawali dengan observasi, identifikasi potensi dan peluang penciptaan wirausaha baru, pembentukan kelompok, produksi dan pemasaran produk. Beberapa proses yang dilalui dalam rangka memproduksi produk olahan ikan tuna menjadi abon sebagai berikut: (1) mencari bahan utama pembuatan abon yaitu ikan tuna sirip kuning hasil tangkap nelayan Desa Batu Nampar Selatan (Gambar 1); (2) membersihkan ikan tuna, kemudian dilumuri dengan air jeruk nipis dan di diamkan selama 20 menit sampai bau amisnya hilang; (3) pengukusan ikan tuna tersebut hingga dagingnya empuk dan mulia tercium bau wangi; (4) mencampur ikan dengan bumbu yang sudah diblender dengan tujuan memberi rasa gurih; (5) menggoreng memasak ikan yang sudah dibumbu tanpa menggunakan minyak selama kurang lebih 3 jam sampai harus benar-benar kering sehingga produk abon dapat bertahan sampai 3 bulan; (6) pengepakan (packing) produk olahan ikan tuna tersebut ke dalam kemasan terbaik, yaitu kemasan yang mampu mendukung abon untuk dapat bertahan lama, tidak terkontaminasi debu, dan mikroba seperti jamur. Setelah itu diberi stiker label buatan sendiri.

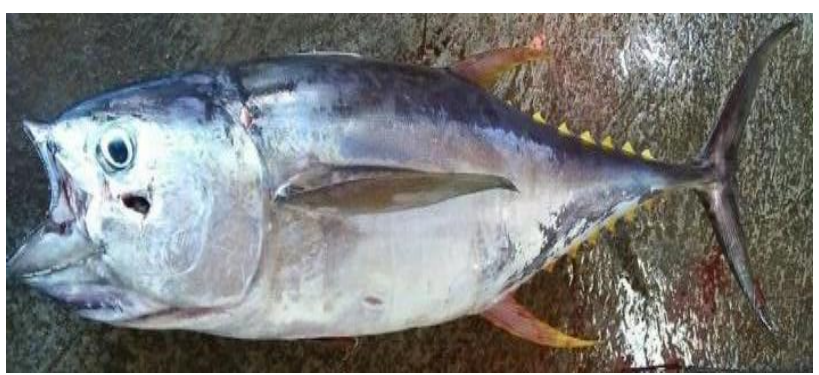

Gambar 1. Ikan tuna sirip kuning 


\section{Hasil dan Pembahasan}

Produk abon merupakan salah satu produk olahan dari bahan baku ikan tuna sirip kuning mendapat respon yang positif dari masyarakat Desa Batu Nampar Selatan (Gambar 2). Hal ini terbukti dari terbentuknya sejumlah kelompok wirausaha. Selain itu, produk olahan ini juga memiliki nilai ekonomi tinggi sehingga promosinya di berbagai media, mulai dari media konvensional sampai media elektronik mendapat respon positif.

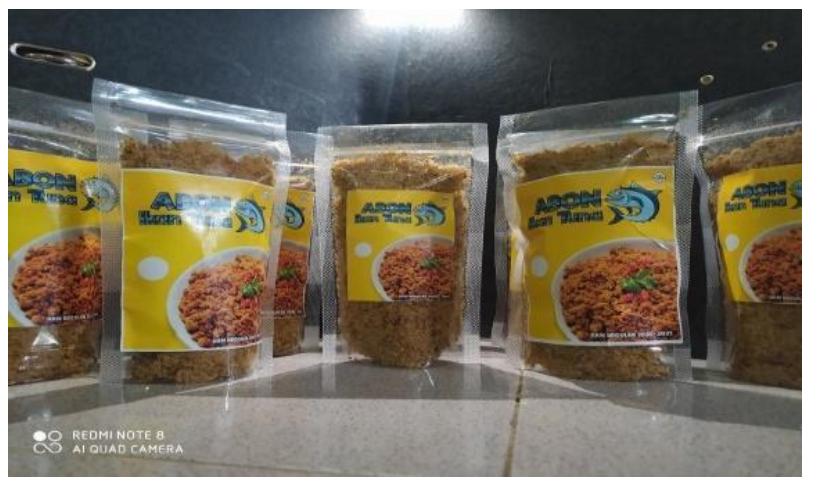

Gambar 2. Produk abon dalam packing

Promosi ini juga bertujuan untuk meningkatkan gairah masyarakat yang tergabung dalam kelompok wirausaha abon ikan tuna tanpa minyak. Kedepan nya mereka diharapkan dapat membuat kelompok usaha produk olahan desa sendiri untuk meningkatkan kualitas hidupnya.

Kendala yang sedikit ditemukan adalah pada kegiatan sosialisasi yang kurang direspon oleh masyarakat. Namun semuanya dapat teratasi setelah Tim yang tergabung dengan Mahasiswa KKN melakukan proses produksi selama beberapa minggu dan berhasil mendapat hasil penjualan, akhirnya masyarakat tertarik dengan jenis usaha yang kami lakukan. Akhirnya kegiatan sosialisasi dan pelatihan kepada masyarakat mengenai jenis usaha pembuatan abon ikan tuna berjalan lancar.

Manfaat yang diperoleh dari kegiatan wirausaha pembuatan abon ini oleh masyarakat Desa Batu Nampar Selatan di antaranya: meningkatkan kesejahteraan anggota masyarakat, meningkatkan silaturahmi masyarakat karena interaksi sosial terjalin dengan baik, melatih kerjasama dalam mengembangkan jenis usaha, dan melatih kemampuan menghadapi dan memecahkan masalah,

Sejalan dengan perkembangan dan tantangan seperti adanya krisis ekonomi sebagai dampak dari pandemic Covid-19, pemahaman kewirausahaan baik melalui pendidikan formal maupun pelatihan-pelatihan di segala lapisan masyarakat menyebabkan kewirausahaan menjadi berkembang.

Pewirausaha (entrepreneur) mempunyai cara berpikir yang berbeda dari kebanyakan orang pada umumnya. Mereka mempunyai motivasi, panggilan jiwa, persepsi dan emosi yang sangat terkait dengan nilai nilai, sikap dan perilaku sebagai manusia unggul. Sebagai gambaran awal tentang seorang wirausaha lebih banyak belajar untuk mandiri, memperoleh penghasilan sendiri dan memahami uang didapatkan bukan dengan mudah tapi perlu usaha, lebih peka dan mengetahui usaha apa yang akan dilakukan.

Hasil evaluasi pelatihan yang dilakukan adalah cukup berhasil meskipun ditemukan sedikit kendala terutama dalam memotivasi anggota masyarakat untuk ikut menjadi peserta wirausaha. Namun dengan adanya dukungan pemerintah desa dan tokoh masyarakat dan agama serta karang, taruna motivasi anggota masyarakat terutama dari kaum ibu dan remaja perempuan, akhirnya mereka sangat antusias mengikuti pelatihan wirausaha ini (Gambar 3).

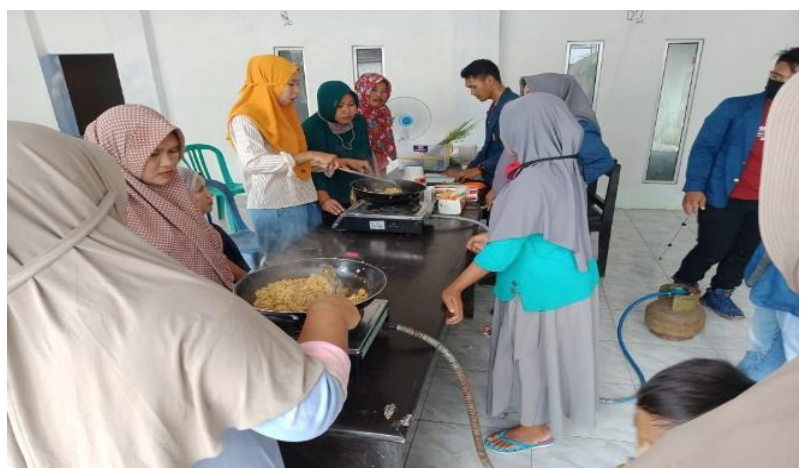

Gambar 3. Pelatihan pembuatan abon

Hasil kegiatan wirausaha ini sesuai dengan argumen yang mendasari keberhasilan wirausaha wanita yang dilaporkan oleh beberapa hasil penelitian bahwa motivasi menjadi faktor penting (Canizares dan Garcia, 2010; Dawson dan Henley, 2012; Forson, 2013).

\section{Kesimpulan}

Berdasarkan hasil analisis dan evaluasi serangkaian program wirausaha produksi abon dari bahan baku ikan tuna sirip kuning yang menjadi program unggulan kegiatan KKN tematik UNRAM, maka dapat disimpulkan bahwa kelompok wirausaha baru Desa Batu Nampar 
Selatan Kecamatan Jerowaru Kabupaten Lombok Timur telah memahami manfaat teknologi pembuatan abon ikan tuna yang dapat meningkatkan nilai simpan ikan. Selain itu, usaha ini juga dapat meningkatkan pendapatan keluarga melalui pengembangan industri rumah tangga berbahan baku lokal dan murah.

\section{Ucapan Terima Kasih}

Pelaksanaan kegiatan pembuatan abon ikan ini dapat berjalan lancar tidak terlepas berkat bantuan dari berbagai pihak, maka pada kesempatan ini penulis mengucapkan banyak terimakasih kepada yang terhormat: Rektor Universitas Mataram, Ketua LPPM Universitas Mataram, Kepala Dinas Sosial Pemerintah Kabupaten Lombok Timur, Kepala Desa Jerowaru Selatan beserta jajarannya, Tokoh Masyarakat, dan semua pihak yang tidak dapat disebutkan satu persatu yang telah membantu mulai dari awal hingga selesainya kegiatan ini.

\section{Daftar Pustaka}

Abdurrahman, N. H. 2013. Manajemen Bisnis Syariah dan Kewirausahaan, Pustaka Setia, Bandung, 2013, hlm. 349.

Abdurrazif, Dedi, Z., Wiwik, F, Ahmad N. A. R., Andrey, D. 2021. Laporan Akhir Program KKN Era New Normal Pngolahan Hasil Laut Ikan Tuna Menjadi Abon. LPPM UNRAM, 2021. 51 hal.

Achmad, N. (2015). Kewirausahaan: Suatu Alternatif Lain Menuju Kesuksesan. Surakarta: BPK FEB UMS.

Ali, M., dan Asrori, M. 2014. Metodologi \& Aplikasi Riset Pendidikan. Jakarta: Bumi Aksara.

BPS Kabupaten Lombok Timur. 2021. Kabupaten Lombok Timur Dalam Angka 2021, 386 hal.

Canizares, S.M.C. dan Garcia, F.J.F. (2010). Gender differences in entrepreneurial attitudes. Equality, Diversity and Inclusion: An International Journal. 29 (8): 766- 786.

Dawson, C. dan Henley, A. (2012). "Push" versus "pull" entrepreneurship: An ambiguous distinction? International Journal of Entrepreneurial Behaviour \& Research. 18 (6): 697-719.
Dzulmawan, M., Geo, L., \& Gafaruddin, A. 2019. Analisis Nilai Tambah Pengolahan Abon Ikan Tuna di Kelurahan Mata Kecamatan Kendari Kota Kendari (Studi Kasus Industri Rumah Tangga Dzakiyah Permata). Jurnal Ilmiah Agribisnis, 4(2): 29-34.

Forson, C. (2013). Contextualising migrant black business women's work-life balance experiences. International Journal of Entrepreneurial Behaviour \& Research. 19 (5): 460-477.

Kusumayanti, H., Astuti, W., \& Broto, R. W. (2011). Inovasi pembuatan abon ikan sebagai salah satu teknologi pengawetan ikan. Gema Teknologi, 16(3), 119-121.

Prihadhi, E. K. 2004. My Potency: LangkahLangkah Praktis Untuk Menemukan dan Mengelola Potensi dengan Daur Aktualisasi Potensi. Elex Media Komputindo. Jakarta. 251 hal.

Setiawati, I., dan Sri, N. 2018 Manajemen Usaha Pengolahan Abon Ikan Lele (Clarias gariepinus) di P2MKP Jaya Mandiri Kecamatan Bulu, Kabupaten Temanggung. Jurnal Penyuluhan Perikanan dan Kelautan, 12(2): 95-110.

Sunyoto, D. 2013. Perilaku Konsumen (Panduan Riset Sederhana untuk Mengenali Konsumen), CAPS (Center of Academic Publishing Service), Yogyakarta, 2013, hlm. 152.

Tjiptono, F. 1995. Strategi Pemasaran, Andi Officet, Yogyakarta, 1995, hlm. 219. 